\title{
TINJAUAN FIQH MUAMALAH TERHADAP JUAL BELI SUKU CADANG BEKAS SEPEDA MOTOR
}

\author{
YUDA FIRMANSYAH
}

\begin{abstract}
ABSTRAK
Saat konsumen memperbaiki sepeda motor di bengkel Desa Upah banyak karyawan yang mengambil suku cadang tersebut serta dijual kembali seperti rantai, baterai dan suku cadang lainnya yang masih bisa diperbaiki. Dari suku cadang bekas dikumpulkan dengan tanpa ijin pemilik suku cadang bekas tersebut, pelaku menjual kepada konsumen yang lainnya untuk dipakai kembali dengan harga yang lebih murah. Rumusan masalah dalam penelitian ini yaitu Bagaimana praktik jual beli suku cadang bekas di Bengkel Desa Upah Kecamatan Bendahara Kabupaten Aceh Tamiang dan Bagaimanakah tinjauan Fiqh Muamalah terhadap praktik jual beli suku cadang bekas di Bengkel Desa Upah Kecamatan Bendahara Kabupaten Aceh Tamiang. Penelitian ini termasuk penelitian lapangan (field reseacrh) yang dilakukan terhadap karyawan bengkel dan konsumen di Desa Upah Kecamatan Bendahara Kabupaten Aceh Tamiang. Jenis penelitian dalam penelitian ini adalah normatif sosiologis yang dilakukan dengan cara melihat fakta-fakta yang terjadi di lapangan yang berhubungan dengan aspekaspek hukum dalam interaksi sosial di dalam masyarakat. Metode pengumpulan data yaitu obeservasi, wawancara tidak terstruktur dan dokumentasi. Dari hasil penelitian, peneliti menyimpulkan bahwa dalam praktik sistem jual beli suku cadang bekas konsumen diberikan opsi saat memperbaiki kendaraan yaitu dengan suku cadang yang baru atau bekas. suku cadang bekas diperoleh dari milik konsumen yang mana suku cadang yang rusak telah diganti dengan yang baru dan yang suku cadang rusak tersebut diambil oleh karyawan tanpa meminta kepada pihak konsumen dan diperbaiki oleh karyawan tersebut dan dijual kembali. jual beli suku cadang bekas sepeda motor di bengkel Desa Upah Kecamatan bendahara Kabupaten Aceh Tamiang ditinjauan sacara Fiqh muamalah, jual beli suku cadang bekas sepeda motor ini tidak diperbolehkan, dikarenakan suku cadang bekas tersebut bukanlah milik karyawan sepenuhnya melainkan milik konsumen. Kepemilikan tersebut belum berpindah kepada karyawan, karena tidak terdapat salah satu dari sebab-sebab kepemilikan.
\end{abstract}

Kata Kunci: Jual Beli, Suku Cadang Bekas, Fiqh Muamalah.

\section{Pendahuluan}

Manusia sebagai makhluk sosial memerlukan orang lain untuk keberlangsungan hidup, mereka saling melengkapi kebutuhan satu sama lain. Adanya ketergantungan yang semacam ini, maka manusia dalam memenuhi kebutuhan hidupnya, perlu menciptakan sesuatu hubungan yang baik antara manusia satu dan lainnya. Tidak terkecuali kegiatan muamalah seperti jual beli, utang piutang, pemberian Upah, serikat usaha, dan lain-lain. Salah satu bentuk muamalah 
didalam Islam adalah jual beli, yakni persetujuan dimana pihak yang satu mengikatkan dirinya untuk menyerahkan suatu benda dan pihak lain membayar harga yang telah disepakati. Dengan kata lain jual beli terjadi apabila dilakukan oleh dua orang atau lebih yang didasari suka sama suka dan didasari kerelaan antara masing-masing pihak yang melakukan transaksi.

Tata aturan semacam ini telah lebih dahulu dijelaskan didalam al-Qur'an surat An-Nisa ayat 29:

Artinya :Hai orang-orang yang beriman, janganlah kamu saling memakan harta sesamamu dengan jalan yang batil, kecuali dengan jalan perniagaan yang berlaku dengan suka sama-suka di antara kamu. Dan janganlah kamu membunuh dirimu; sesungguhnya Allah adalah Maha Penyayang kepadamu. ( QS. An-Nisa: 29)

Islam tidak membatasi kehendak seseorang dalam mencari dan memperoleh harta selama yang demikian tetap dilakukan dalam prinsip umum yang berlaku yaitu yang halaldan baik. Hal ini berarti Islam melarang seseorang untuk mencari kekayaan sebanyak mungkin. Karena bagaimanapun yang menentukan kekayaan yang dapat diperoleh seseorang adalah Allah Swt sendiri.

Sebagaimana disebutkan dalam Firman Allah Swt Q.S al-Jumu'ah ayat 4:

Artinya:Demikianlah karunia Allah, diberikan-Nya kepada siapa yang dikehendaki-Nya; dan Allah mempunyai karunia yang besar.(Q.S Al-Jumu'ah:4).

Selain itu dalam pandangan Islam harta itu bukan tujuan tetapi adalah alat untuk menyempurnakan kehidupan dan alat untuk mencapai keridhaan Allah. ${ }^{1}$

Saat ini transportasi merupakan hal penting dalam keberlangsungan kehidupan manusia, karena transportasi bisa membantu keberlangsungan perekonomian contohnya seperti mobil dan sepeda motor yang melakukan inovasi terbaru untuk menarik pembeli. Seiring dengan pengunaannya ada hal yang perlu diperhatikan dalam merawat sepeda motor ataupun mobil yang kondisi mesin yang harus dikontrol, salah satunya rutin mengantikan suku cadang.

\footnotetext{
${ }^{1}$ Amir Syarifuddin, Garis-Garis Besar Fiqh, (Jakarta: Kencana, 2003), h. 182
} 
Suku cadang berfungsi sebagai keamanan motor dari kerusakan yang digunakan sehari. Dalam pergantian suku cadang biasanya konsumen akan mengatikan suku cadang yang sudah tidak bisa digunakan lagi dengan suku cadang yang baru karena sudah berkurang fungsinya.

Permasalahan terjadi saat karyawan Bengkel di Desa Upah Kecamatan Bendahara Kabupaten Aceh Tamiang, yang menjual suku cadang bekas seperti karburator, rantai, shock, piringan dan suku cadang lainnya yang masih bisa dipakai. Dari suku cadang yang masih bisa dipakai dikumpulkan dengan tanpa seijin pemilik suku cadang bekas tersebut, si pelaku menjual kepada konsumen untuk dipakai kembali dengan harga yang lebih murah dari harga barunya. $^{2}$

Didalam pembelian ini terjadinya barang yang diperjualbelikan tidak memenuhi syarat dalam jual beli, dimana syarat jual beli ialah barang yang diperjualbelikan harus milik penjual. ${ }^{3}$ Dengan jual beli suku cadang bekas ini akan menjadi "barang curian" dimana si pelaku tidak meminta ijin kepada pemilik barang dan menjadikan adat kebiasaan bagi para karyawan bengkel di desa Upah Kecamatan Bendahara Kabupaten Aceh Tamiang.

\section{LANDASAN TEORI}

Pengertian Jual beli syara" adalah tukar menukar harta dengan harta untuk memiliki dan memberi kepemilikan. Jual beli atau perdagangan dalam istilah etimologi berarti menjual atau mengganti. ${ }^{4}$ Adapun pengertian jual beli menurut istilah yaitu tukar menukar barang atau barang dengan uang yang dilakukan dengan jalan melepaskan hak milik dari yang satu kepada yang lain atas dasar saling merelakan. ${ }^{5}$

\footnotetext{
${ }^{2}$ Observasi penulis pada tanggal 27 februari 2020 pada pukul 10:00 WIB.

${ }^{3}$ Nasrun Haroen, Fiqh Muamalah, (Jakarta:Gaya Media Pratama,2000), h.115-119

${ }^{4}$ Abdul Rahman Ghazali, Ghufron Ihsan, Sapiudin Shidiq, Fiqih Muamalat, (Jakarta: Kencana Prenada Media Group, 2010), h. 67.

${ }^{5}$ Ruf'ah Abdulah, Fikih Muamalah, (Bogor: Ghalia Indonesia, 2011), h. 65.
} 
Jual beli secara bahasa artinya memindahkan hak milik terhadap benda dengan akad saling mengganti. ${ }^{6}$ Jual beli atau dalam bahasa Arab al-bai ${ }^{\text {ee }}$ menurut etimologi adalah tukar menukar sesuatu dengan sesuatu yang lain. Menurut istilah jual beli disebut dengan bay, yang berarti menjual, mengganti dan menukar sesuatu dengan sesuatu yang lain. ${ }^{7}$

Imam Taqiyuddin mendefinisikan jual beli adalah tukar menukar harta, saling menerima, dapat dikelola (tasharruf) dengan ijab dan qabul, dengan cara yang sesuai dengan Islam. Sayid Sabiq mengartikan jual beli menurut bahasa adalah tukar menukar secara mutlak. ${ }^{8}$

\section{Dasar Hukum Jual Beli}

Jual beli ialah sarana tolong menolong sesama umat manusia untuk memenuhi kebutuhan hidup dimana memiliki landasan hukum yang kuat dari al-Qur'an dan Sunah Rasulullah SAW. Terdapat beberapa ayat al-Qur'an dan Sunnah Rasulullah SAW yang membahas tentang jual beli yaitu: ${ }^{9}$

a. Surat al-Baqarah ayat 275 :

Artinya: orang-orang yang Makan (mengambil) riba tidak dapat berdiri melainkanseperti berdirinya orang yang kemasukan setan lantaran (tekanan) penyakitgila. Keadaan mereka yang demikian itu, adalah disebabkan mereka berkata(berpendapat), Sesungguhnya jual beli itu sama dengan riba, Padahal Allahtelah menghalalkan jual beli dan mengharamkan riba. Orang-orang yang telahsampai kepadanya larangan dari Tuhannya, lalu terus berhenti (darimengambil riba), Maka baginya apa yang telah diambilnya dahulu (sebelumdatang larangan); dan urusannya (terserah) kepada Allah. Orang yang kembali(mengambil riba), Maka orang itu adalah penghuni-penghuni neraka; merekakekal di dalamnya. (Q.S al-Baqarah: 275)

Dalam ayat ini Allah menceritakan sifat orang yang menyalah gunakan kalimat menolong atau membantu, padahal sebenarnya ia mencari keuntungan bahkan mencekik dan menghisap darah. Mereka adalah pemakan riba. Allah menyatakan, bahwa mereka yang

\footnotetext{
${ }^{6}$ Abdul Aziz Muhammad Azzam, Fiqh Muamalat (Sistem Transaksi dalam Islam), (Jakarta: Bumi Aksara, 2010), h. 23.

${ }^{7}$ Nasrun Haroen, Fiqh Mu"amalah,... h. 2.

${ }^{8}$ Sayid Sabiq, ,Fikih Sunnah, (Semarang: Karya Toha Putra, 1999), h. 49.

${ }^{9}$ Abdul Rahman Ghazaly Dkk, Fiqh Muamalat,....h. 68
} 
memakan riba tak akan dapat berdiri tegak dalam hidupnya ditengah masyarakat, melainkan bagaikan orang kesurupan setan. ${ }^{10}$

Allah Maha Mengetahui dan Maha Bijaksana, yang mengetahui hakikat dan akibat dari segala sesuatu yang berguna sehingga dibolehkan dan yang berbahaya diharamkan-Nya. Sebab Allah itu sayang kepada hamba-Nya melebihi kasih sayang ibu terhadap anaknya yang masih bayi. ${ }^{11}$

Berdasarkan penafsiran ayat di atas Allah menegaskan bahwa telah dihalalkan jual beli dan diharamkan riba. Orang-orang yang membolehkan riba dapat ditafsirkan sebagai pembantahan hukum-hukum yang telah ditetapkan oleh Allah Yang Maha Mengetahui lagi Maha Bijaksana. Maka perlu diperhatikan untuk selalu menjaga agar terhindar dari praktik riba, termasuk dalam jual beli, agar terhindar dari hal-hal yang diharamkan maupun yang syubhat (perkara yang hukumnya berada diantara halal dan haram).

b. an-Nisa' ayat 29 :

Artinya: Hai orang-orang yang beriman, janganlah kamu saling memakan harta sesamamu dengan jalan yang batil, kecuali dengan jalan perniagaan yangBerlaku dengan suka sama-suka di antara kamu. dan janganlah kamu membunuh dirimu, Sesungguhnya Allah adalah Maha Penyayang kepadamu. (Q.S an-Nisa: 29)

Ayat diatas menjelaskan bahwa Allah melarang hamba-hamba-NYA yang beriman memakan harta satu sama lain dengan cara yang batil, yakni dengan usaha-usaha yang tidak syar'i seperti berbagai macam riba, judi dan seluruh model penipuan, dimana Allah mengetahui bahwa pelakunya hanya sekedar membuat tipuan untuk lolos dari jeratan riba. Tentang orangorang yang beriman, jangan lah kalian mengambil harta orang lain dengan cara tidak benar. Kalian diperbolehkan melakukan perniagaan yang berlaku secara suka sama suka. Jangan menjerumuskan diri kalian dengan melanggar perintah-perintah tuhan. Jangan pula kalian

\footnotetext{
${ }^{10}$ Ibnu Katsir, Tafsir Ibnu Katsir, Jilid I,Terj: Salim Bahreisy dan Said Bahreisy, (Jakarta: PT. Bina Ilmu, 2005), h. 538.

${ }^{11}$ Ibid, ...h.589.
} 
membunuh orang lain, sebab kalian semua berasal dari satu nafs. Allah selalu melimpahkan rahmat-NYA kepada kalian.

Dasar hukum jual beli berdasarkan Sunnah Rasulullah SAW, yaitu:

$a$. Hadis yang diriwayatkan oleh Rifa'ah ibn Rafi'

Artinya: "Rasulullah SAW.ditanya oleh salah seorang sahabatmengenai pekerjaan (Profesi) apa yang paling baik. Rasulullah SAW. Menjawab: usaha tangan manusia sendiri dan setiap jual beli yang diberkati" (HR. Al-Bazzar dan Al-Hakim). ${ }^{12}$

Hadis diatas menjelaskan bahwa pekerjaan yang paling baik itu ialah pekerjaan yang kita kerjakan dengan usaha tangan kita sendiri dan jual beli yang diberkati, sehingga rezeki yang kita peroleh itu akan diberkati.

b. Hadis dari al-Baihaqi, Ibn Majah dan Ibn Hibban, Rasulullah menyatakan

Artinya: "dari Abu said al-Khudri bahwa Rasulullah SAW bersabda: sesungguhya jual beli itu harus dilakukan secara suka sama suka”. (HR. Al-Baihaqi dan Ibnu Majah, dan dinilai shahih oleh Ibnu Hibbah) ${ }^{13}$

Hadis diatas menjelaskan bahwa jual beli itu harus dilakukan atas dasar suka sama suka sehingga terjadi nya keridhaan dalam jual beli tersebut.

Dari isi kandungan ayat-ayat al-Qur'an dan hadis Rasulullah di atas, para ulama fikih menyatakan bahwa hukum asal jual beli itu ialah mubah (boleh). Akan tetapi, sebagaimana dikutip oleh imam asy-Syatibi (w. 790H), pakar fikih Maliki, hukumnya boleh berubah menjadi wajib. Imam asy-Syatibi memberi contoh ketika terjadi praktek ihtikar (penimbunan barang sehingga stok dipasar dan harga menjadi naik secara drastis).

Jika seseorang melakukan ihtikar dan mengakibatkan melonjaknya harga barang yang ditimbunnya itu, maka menurutnya, pihak pemerintah boleh memaksa pedagang menjual barang tersebut dengan harga sebelumnya kepada masyarakat karena barang tersebut sangat dbutuhkan oleh masyarakat dengan ketentuan pemerintah.

\footnotetext{
12 Ibid.,

${ }^{13}$ Muhammad Nashruddin al Albani, Shahih Sunan Ibni Majah, Terj: Ahmad Taufik Abdurrahman, Jilid 2 (Jakarta: Pustaka Azzam, 2007), h.313.
} 
Hal ini sesuai dengan prinsip al-Syatibi bahwa yang mubah itu apabila diitinggal secara total, maka hukumnya menjadi wajib. Apabila sekelompok pedagang besar melakukan boikot tidak mau menjual beras lagi, pihak pemerintah boleh memaksa untuk berdagang beras dan para pedagang ini wajib melaksanakannya demikian pula dalam komoditi-komoditi lainnya. ${ }^{14}$

2. Rukun dan Syarat Jual Beli.

Jual beli memiliki rukun dan syarat yang harus terpenuhi, sehingga jual beli itu bisa dikatakan sah secara hukum Islam. Dalam Rukun jual beli terdapat perbedaan pendapat ulama Hanafiyah dengan Jumhur ulama.

Rukun jual beli menurut ulama Hanafiyah Cuma satu, ialah ijab (ucapan membeli dari pembeli) dan Kabul (ucapan menjual dari penjual). Menurut mereka, yang menjadi rukun jual beli itu ialah kerelaan (rida/taradhi) kedua belah pihak untuk melaksanakan jual beli. ${ }^{15}$

Menurut Jumhur ualama mengatakan bahwa rukun jual beli itu terdapat 4 unsur, Yaitu:

a. Adanya orang yang berakad atau al-Muta'aqidain (penjual dan pembeli)

b. Ada shighat (lafal ijab dan kabul)

c. Ada barang yang diperjual belikan

d. Ada harga terhadap barang yang diperjual belikan ${ }^{16}$.

Menurut ulama Hanafiyah, orang yang berakad, barang yang dibeli, dan nilai tukar barang termasuk kedalam syarat-syarat jual beli, bukan rukun jual jual beli. ${ }^{17}$

Adapun syarat jual beli disesuaikan dengan rukun jual beli menurut Jumhur ulama diatas ialah sebagai berikut:

a. Syarat-syarat orang yang berakad.

\footnotetext{
${ }^{14}$ Abdul Rahman Ghazaly Dkk, Fiqh Muamalat,.....h. 70

${ }^{15}$ Ibid..., h. 71.

${ }^{16}$ Nasrun Haroen, Fiqh Muamalah, ....h. 115.

${ }^{17}$ Abdul Rahman Ghazaly Dkk, Fiqh Muamalat,.....h. 71.
} 
Para ulama fiqh sepakat bahwa orang mengerjakan akad jual beli harus memenuhi syarat antara lain:

1) Berakal. Berakal disini jual beli yang telah mumayiz, jika dilakukan anak kecil dan orang gila tidak berlaku jual beli itu (tidak sah jualbeli).

2) Yang melakukan akad itu adalah orang yang berbeda, maksudnya ialah sipenjual tidak bisa membeli barang nya sendiri.

b. Syarat-syarat yang terkait dalam ijab Kabul.

Unsur utama dari jual beli yaitu kerelaan dari kedua pihak. Kerelaan dua belah pihak dapat dilihat dari ijab dan Kabul yang dilangsungkan, menurut mereka ijab dan Kabul perlu dibicarakan secara jelas dalam transaksi.Transaksi yang mengikat kedua belah pihak, yaitu akad jual beli, sewa-menyewa dan akad nikah. Transaksi yang hanya mengikat satu pihak ialah wasiat, hibah dan wakaf.

c. Syarat-syarat barang yang diperjualbelikan ( $m a$ 'qud 'alaih)

Syarat barang yang harus diperjualbelikan antara lain sebagai berikut:

1) Barang itu ada, barang tersebut harus ada saat dalam jual beli terkecuali penjual sanggup menyatakan bahwa barang itu ada maka itu boleh.

2) Dapat dimanfaatkan dan bermanfaat bagi manusia. Barang

3) Milik seseorang maksudnya ialah barang yang sifatnya belum dimiliki seseorang tidak boleh diperjualbelikan, contohnya menjual ikan didalam laut atau menjual emas dalam tanah, karena ikan dan emas belum dimiliki. Jadi barang yang diperjualbelikan jelas punya sipenjual.

4) Boleh diserahkan saat akad berlangsung atau pada saat waktu yang telah disepakati kedua belah pihak.

d. Syarat uang atau nilai tukar barang yang dijual:

1) Suci. Barang yang diperjual belikan harus suci tidak boleh bernajis. 
2) Ada manfaatnya

3) Keadaan barang/ uang dapat diserah terimakan.

4) Barang yang diperjualbelikan milik penjual.

5) Barang itu harus diketahui oleh pembeli dan penjual. ${ }^{18}$

Disamping itu syarat-syarat yang berkaitan dengan rukun jual beli yang sudah ditulis diatas, para ulama figh juga mengemukakan syarat lainnya, ialah:

a. Syarat sah jual beli para ualama figh menyatakan suatu jual beli dinyatakan sah apabila:

1) Jual beli itu terhindar dari cacat maupun dari segi barang, harga, akad, ataupun ada unsure paksaan, tipuan dan mudarat.

2) Apabila barang yang diperjualbelikan itu benda bergerak, maka barang itu boleh langsung dikuasai pembeli dan harga barang dikuasai si penjual. Adapun barang yang tidak bergerak boleh dikuasai pembeli setelah surat mennyuratnya diselesaikan sesuai dengan 'Urf(kebiasaan) setempat.

b. Syarat yang terkait dengan jual beli, ialah :

1) Yang berakad sudah mumayiz (cakap hukum) memiliki kekuasaan terhadap melakukan jual beli.

2) Barang yang diperjualbelikan milik sipenjual.

c. Syarat yang terkait dengan kekuatan hukum akad jual beli. Para ulama fiqh sepakat bahwa suatu jual beli baru bersifat mengikat apabila jual beli itu terbebas dari hak khiyar (hak pilih untuk melanjutkan atau membatalkan jual beli). Jikajual beli itu masih memiliki hak khiyar, maka jula beli itu belum bersifat mengikat dan masih bisa membatalkan jual beli tersebut. ${ }^{19}$

\footnotetext{
${ }^{18}$ Nasrun Haroen, Fiqh Muamalah, ....h. 115-119.

${ }^{19}$ Abdul Rahman Ghazaly Dkk, Fiqh Muamalat,.....h. 77-78.
} 


\section{Bentuk-Bentuk Jual Beli yang Dilarang}

Jual beli yang dilarang terbagi dari dua yaitu : pertama, jual beli yang dilarang dan hukumnya tidak sah(batal), ialah jual beli yang tidak memenuhi syarat dan rukun, kedua, jual beli yang hukumnya sah tetapi dilarang, yaitu jual beli yang telah memenuhi syaratdan rukunnya, tetapi ada beberapa faktor yang menghalang kebolehan proses jual bei.

a. Jual beli terlarang karena tidak memenuhi syarat dan rukun.

Bentuk jual beli yang termasuk dalam kategori ini sebagai berikut:

1) Jual beli barang yang zatnya haram, najis, atau tidak boleh diperjualbelikan.Adapun bentuk jual beli yang dilarang karena barangnya yang tidak boleh diperjualbelikan yaitu air susu ibu dan air mani (sperma) binatang. ${ }^{20}$

2) jual beli yang dilarang karena belum jelas (samar-samar)

Antara lain:

a) Jual beli buah-buahan yang belum tampak hasilnya.

b) Jual beli barang yang belum tampak. Contohnya menjual ikan dikolam/laut, ubi/singkong yang masih ditanam dan anak ternak yang masih dalam kandungan induknya.

3) Jual beli bersyarat.

4) Jual beli yang menimbulkan kemudaratan.

5) Jual beli yang dilarang karena dianiaya.

6) Jual beli muhaqalah, yaitu menjual tanam-tanaman yang masih disawah atau diladang.

7) Jual beli Mukhadarah, yaitu menjual buah-buahan yang masih hijau (belum pantas dipanen).

\footnotetext{
${ }^{20} \mathrm{Ibid}, \ldots$, h. $80-85$.
} 
8) Jual beli mulamasah yaitu jual beli secara sentuh-menyentuh.

9) Jual beli munabadzah, yaitu jual beli secara lempar-melempar.

10) Jual beli muzabanah, menjual buah yang basah dengan yang kering

b. Jual beli terlarang karena ada faktor lain yang merugikan pihak-pihak terkait, antara lain:

1) Jual beli dari orang yang masih dalam tawar-menawar.

2) Jual beli dengan menghadang dagangan diluar Kota/pasar.

3) Membeli barang dengan mendorong untuk ditimbun, kemudian akan dijual ketika harga naik karena kelangkaan barang tersebut.

4) Jual beli barang rampasan atau curian. ${ }^{21}$

Hak milik (kepemilikan) adalah hubungan antara manusia dengan harta yang ditetapkan oleh syara', dimana manusia memiliki kewenangan khusus untuk melakukan transaksi terhadap harta tersebut, sepanjang tidak ditentukan hal-hal yang melarangnya. Kepemilikan adalah sesuatu yang dimiliki oleh manusia, baik berupa harta benda (dzat) atau nilaimanfaat. $^{22}$

Dari pengertian tentang kepemilikan, macam-macam kepemilikan dibagi menjadi dua yaitu milk at tam dan milk an-naqis.Milk at tammberupa kepemilikan yang meliputi benda dan manfaatnya. Sedangkan milk an-naqis yaitu kepemilikan yang hanya memiliki salah satu dari benda tersebut (manfaat atau benda). ${ }^{23}$

Milik didefinisikan sebagai berikut:

Artinya: "Kekhususan terdapat pemilik suatu barang menurut syara' untuk bertindak secara bebas bertujuan mengambil manfaatnya selama tidak ada penghalang syar ${ }^{i}$. "24 Kata milkiyah itu asalnya daripada milk dan malakiyah itu asalnya dari malakah. Malakah juga salah satu maknanya, milik. Makna ini bukan dari malakah yang dikatakan

\footnotetext{
${ }^{21}$ Ibid,..., h. 85-87.

${ }^{22}$ Hendi Suhendi, Fiqh Muamalah,(Jakarta: Rajawali, 2005),h.36.

${ }^{23}$ Dimyuddin Djuwani, Pengantar Fiqh Muamalah, (Yogyakarta: Pustaka Pelajar, 2008), h.40.

${ }^{24}$ Hendi Suhendi, Fiqh Muamalah, (Jakarta: PT Raja Grafindo,2002), h.33.
} 
malakah hukmi (daya kekuatan akal buat menetapkan hukum) dan malakah idrak (daya akal buat memahamkan sesuatu). ${ }^{25}$ Milk menurut lughah ialah: Memiliki sesuatu dan sanggup bertindak secara bebas terhadapnya. Milk menurut istilah ialah: Sesuatu ikhitsas yang menghalangi yang lain, menurut syara' yang membenarkan si pemilik ikhtisas itu bertindak terhadap barang yang miliknya sekehendaknya, kecuali ada penghalang. ${ }^{26}$

Apabila seseorang telah memiliki suatu benda yang sah menurut syara’, orang tersebut bebas bertindak terhadap benda tersebut, baikakan dijual maupun akan digadaikan, baik dia sendiri maupun dengan perantara orang lain. ${ }^{27} \mathrm{Al}$-Milikiyah atau Al-Milku (Kepemilikan, hak milik) adalah hubungan keterikatan antara seseorang dengan harta yang dikukuhkan keabsahannya oleh syara' yang hubungan keterikatan itu menjadikan harta tersebut hanya khusus untuknya dan ia berhak melakukan semua bentuk pentasharufan terhadap harta itu selagi tidak ada suatu hal yang menjadi penghalang dirinya dari melakukan pentasharufan. ${ }^{28}$

Al-Milku secara etimologi artinya adalah penguasaan seseorang terhadap harta, dalam artian hanya dirinya yang berhak melakukan pentasharufan terhadapnya. Para fuqaha mengemukakan sejumlah definisi Al-Milku yang kesemuanya hampir mirip serta memiliki kandungan maksud dan makna yang sama.

Oleh karena itu, jika ada seseorang menguasai dan mendapatkan harta dengan cara yang legal, maka harta itu terkhusus untuknya, dan keterkhususan harta itu untuknya membuatnya bisa memanfaatkannya dan mentasharufkannya kecuali jika ada alasan atau sebab yang ditetapkan syara' yang menghalanginya dari melakukan hal itu, seperti gila, idiot, sifat as-safah (boros), masih anak-anak dan lain sebagainya. Sebagaimana pula, keterkhususan harta itu untuknya menghalangi orang lain dari memanfaatkan atau melakukan pentasaharufan

25 Muhammad Hasbi Ash Shiddieqy, Pengantar Fiqh Muamalah,(Semarang: Pustaka Rizki Putra, 1999),h.11.

${ }^{26}$ Muhammad Hasbi Ash Shiddieqy, Pengantar Fiqh Muamalah...,h.11.

${ }^{27}$ Ibnu Qasim al-Ghazi, Fathul al-Qarib, Terj: Imron Abu Amar, (Kudus: Menara Kudus,1982),h.326.

${ }^{28}$ WahbahAz-Zuhayli, al-Fiqh al-Islam wa Adillatuhu, Terj: Abdul Hayyie al-Kattani, dkk, Peny: Nuim Hidayat, jilid 6,cet: 1,(Jakarta: Gema Insani, 2011), h.449. 
terhadap harta tersebut kecuali jika ada alasan atau sebab ditetapkan oleh syara' yang memperbolehkan hal itu untuknya, seperti perwalian, al-wishaayah (pengampuan, ditunjuk sebagai washi) atau perwakilan. ${ }^{29}$

Pada dasarnya harta bisa untuk dimiliki, hanya saja terkadang muncul suatu hal yang dalam semua keadaan atau dalam beberapa keadaan menjadikannya tidak bisa untuk dimiliki. Berdasarkan hal ini, harta dalam kaitannya dengan bisa tidaknya untuk dimiliki terbagi menjadi 3 macam:

a. Harta yang sama sekali tidak bisa dimilikan (at-Tamliik, menjadikannya milik orang lain) dan tidak pula bisa dimiliki oleh diri sendiri, yaitu harta yang dikhususkan untuk kepentingan dan kemanfaatan umum, seperti jalan umum, jembatan, benteng, rel kereta api, sungai, museumm perpustakaan dan lain sebagainya.

b. Harta yang tidak bisa dimiliki kecuali dengan adanya sebab yang ditetapkan oleh syara' yang karena dengan adanya sebab tersebut harta itu bisa untuk dimiliki, seperti harta wakaf dan aset-aset baitul maal (aset-aset negara), atau yang dikenal dengan sebutan aset bebas menurut istilah pakar hukum.

c. Harta yang bisa dimiliki (at-Tamalluk) dan dimilikkan (at-Tamliik) secara mutlak tanpa adanya suatu syarat atau pembatasan tertentu, yaitu harta selain kedua macam diatas. $^{30}$

\section{Pembagian Hak Kepemilikan}

Berbicara masalah pembagian hak, maka jumlah dan macamnya banyak sekali, antara lain dalam pengertian umum, hak dapat dibagi menjadi dua bagian, yaitu hak mal dan hak ghairmal. Adapun pengertian hak mal:Sesuatu yang berpautan dengan harta, seperti pemilikan

\footnotetext{
${ }^{29}$ Ibid,..., h.450.

${ }^{30} \mathrm{Ibid}, \ldots .$, h.451.
} 
benda-benda atau utang-utang.Hak ghairmal terbagi dua bagian, yaitu hak syakhshi dan hak 'aini. Pengertian hak syakhshi adalah Sesuatu tuntunan yang ditetapkan syara' dari seseorang terhadap orang lain.Hak 'aini ialah hak orang dewasa dengan bendanya tanpa dibutuhkan orang kedua. Hak 'aini ada dua macam: ashli dan thab'i. Hak 'aini ashli ialah adanya wujud benda tertentu dan adanya shabul al-haq, seperti hak milikiyah dan hak irtifa'. Hak 'aini thab'i ialah jaminan yang ditetapkan untuk seseorang yang menguntungkan uangnya atas yang berhutang. Apabila yang berhutang tidak sanggup membayar, maka murtahin berhak menahan barang itu.

Macam-macam hak 'aini ialah sebagai berikut: ${ }^{31}$

a. Haq al-miliki ialah hak yang memberikan pemiliknya hak wilayah. Boleh dia memiliki, menggunakan, mengambil manfaat, menghabiskannya, merusakkannya, dan membinasakannya, dengan syarat tidak menimbulkan kesulitan bagi orang lain.

b. Haq al-intifa' ialah hak yang hanya boleh dipergunakan dan diusahakan hasilnya. Haqal-Isti'mal (menggunakan) terpisah dari haq al istiqlal (mencari hasil), misalnya rumah yang diwakafkan untuk didiami. Si mauquf 'alaih hanya boleh mendiami, ia tidak boleh mencari keuntungan dari rumah itu. ${ }^{32}$

c. Haq al-irtifa' ialah hak memiliki manfaat yang ditetapkan untuk suatu kebun atas kebun yang lain, yang dimiliki bukan oleh pemilik kebun pertama.

d. Haq al-istihan ialah hak yang diperoleh dari harta yang digadaikan. Rahn menimbulkan hak 'aini bagi murtahin, hak itu berkaitan dengan harga barang yang digadaikan, tidak berkaitan dengan zakat benda, karena rahn hanyalah jaminan belaka. $^{33}$

2. Macam-macam Kepemilikan

a. Kepemilikan Sempurna atau Utuh

\footnotetext{
${ }^{31}$ Sohari Sahrani dan Ru'fah Abdullah, Fikih Muamalah, (Bogor: Ghalia Indonesia, 2011), h.35-36.

${ }^{32}$ Ibid,..., h.36-37.

${ }^{33}$ Ibid,..., h.37.
} 
Kepemilikan sempurna atau utuh yaitu kepemilikan atas sesuatu secara keseluruhan, baik zatnya (bendanya) maupun kemanfaatannya (penggunaanya), sekiranya si pemilik memiliki semua hak-hak yang diakui hukum terhadap sesuatu tersebut. Di antara karakteristiknya yang terpenting adalah bahwa itu adalah kepemilikan yang mutlak, permanen yang tidak terbatasi oleh masa tertentu selama sesuatu yang dimiliki itu masih ada, dan tidak bisa digugurkan (maksudnya menjadikan sesuatu itu tanpa pemilik). Oleh karena itu, seandainya ada seseorang mengghasab (menyerobot) suatu barang milik orang lain, lalu si pemilik barang itu berkata, “Aku menggugurkan kepemilikanku”, maka kepemilikannya tidak bisa gugur dan barang itu statusnya tetap menjadi miliknya. Akan tetapi yang bisa dilakukan hanyalah memindahkan kepemilikan. Karena tidak boleh sesuatu itu tanpa ada pemilik. Pemindahan kepemilikan bisa melalui cara akad yang memindahkan suatu kepemilikan seperti jual beli, warisan atau wasiat. ${ }^{34}$

Seseorang yang memiliki kepemilikan sempurna terhadap sesuatu diberi kewenangan yang utuh berupa kebebasan menggunakan, mengembangkan, menginvestasikan dan melakukan pentasharufan terhadap sesuatu miliknya itu sekehendak dirinya. Oleh karena itu ia boleh menjualnya, menghibahkannya, mewakafkannya atau mewasiatkannya. Sebagaimana pula ia juga boleh meminjamkannya dan menyewakannya, Karena ia memang memiliki sesuatu itu secara keseluruhannya, yaitu bendanya dan kemanfaatannya sekaligus. Maka oleh karena itu, ia boleh melakukan pentasharufan terhadap bendanya dan kemanfaatannya sekaligus, ataupun hanya kemanfaatannya.

Apabila si pemilik merusak apa yang ia miliki, maka tidak ada denda apa pun atas dirinya. Karena tidak mungkin ada sifat sebagai pemilik dan sebagai pembayar

\footnotetext{
${ }^{34}$ WahbahAz-Zuhayli, al-Fiqh al-Islam wa Adillatuhu, Terj: Abdul Hayyie al-Kattani, dkk...,h.451.
} 
denda sekaligus pada satu individu. Dengan kata lain, tidak bisa ada satu individu memiliki dua status, status sebagai pemilik sesuatu dan status sebagai pihak yang harus membayar denda atas pengrusakan sesuatu tersebut. Akan tetapi ia terkena sanksi agama (dosa), sebab merusakkan harta hukumnya adalah haram. Namun terkadang, mungkin ia juga bisa terkena sanksi hukum, yaitu diberlakukannya alhajr(pengampuan) terhadap dirinya jika memang terbukti bahwa ia memiliki sifat $\operatorname{safah}$ (boros). ${ }^{35}$

\section{b. Kepemilikan Tidak Sempurna}

Kepemilikan tidak sempurna yaitu kepemilikan sesuatu akan tetapi hanya zatnya (bendanya) saja, atau kemanfaatannya (penggunaannya) saja. Kepemilikan kemanfaatannya atau penggunaannya sesuatu (milkul manfaatan) disebut hak pemanfaatan atau hak penggunaan (haqqul intifaa'). Kepemililkan terhadap kemanfaatan atau hak penggunaan sesuatu bisa berupa hak yang bersifat personal (haqq syakhsyi) bagi si pemilik hak penggunaan tersebut, maksudnya hak itu mengikuti individu pemilik hak tersebut bukan mengikuti zat atau bendanya. Misalnya, al Muushaa lahu (seseorang yang diberi harta wasiatan) berupa pemanfaatan sesuatu selama hidupnya (sehingga apabila ia telah meninggal dunia, maka berakhir pula hak tersebut). Atau bisa berupa hak yang bersifat kebendaan (haqq 'aini) maksudnya hak itu mengikuti bendanya tanpa memperdulikan individu yang memanfaatkan dan menggunakannya (sehingga, hak itu bisa berpindah-pindah dari satu individu ke individu yang lain). Ini disebut haqqul irtifaaq (di bagian mendatang akan dijelaskan maksudnya) dan hanya berlaku untuk harta tidak bergerak. ${ }^{36}$

c. Macam-macam Kepemilikan Tidak Sempurna 
Berdasarkan keterangan di atas, maka kepemilikan tidak sempurna ada tiga macam:

1) Kepemilikan terhadap sesuatu, akan tetapi hanya bendanya saja (milkul'ain) Kepemilikan terhadap sesuatu, akan tetapi hanya bendanya saja (milkul'ain) yaitu sesuatu yang bendanya milik seseorang sedangkan penggunaannya dan kemanfaatan-kemanfaatannya milik orang lain, misalnya seperti si A mewasiatkan untuk si B bahwa ia (si B) boleh menempati rumah si A atau menggarap sawahnya selama si B hidup atau selama tiga tahun misalnya, maka ketika si A meninggal dunia dan si B menerima wasiat itu, maka rumah itu, maksudnya bendanya tetap milik ahli waris si A berdasarkan hak waris. Berdasarkan keterangan di atas, nampak bahwa hanya kepemilikan benda (milkul 'ain) saja yang bisa bersifat permanen dan akan selalu berujung kepada kepemilikan sempurna (yaitu ketika batas waktu pemanfaatannya telah habis). ${ }^{37}$

2) Kepemilikan atas manfaat suatu barang yang bersifat personal atau hak pemanfaatan dan penggunaan (haqqul intifaa')

Adapun sebab atau faktor munculnya kepemilikan manfaat atau hak pemanfaatan dan penggunaannya, yaitu, peminjaman, penyewaan, pewakafan, wasiat dan al-Ibaahah (pembolehan).

Menurut pendapat ulama Syafi'iyah sebagaimana dikutip Wahbah az Zuhayli, mengatakan peminjaman adalah pembolehan terhadap kemanfaatan (ibaahatul manfa'ah, pembolehan memanfaatkan dan menggunakan) tanpa suatu ganti imbalan (cuma-cuma). Maka oleh karena itu, berdasarkan definisi ini, si peminjam 
tidak boleh meminjamkan barang yang dipinjamnya kepada orang lain (orang ketiga). ${ }^{38}$

Sedangkan penyewaan (ijaarah) adalah, pemilikan manfaat dengan suatu ganti imbalan (Upah, biaya, sewa). Pihak yang menyewa boleh memanfaatkan dan menggunakan sendiri barang yang disewanya itu atau dimanfaatkan oleh orang lain secara cuma-cuma maupun dengan biaya, jika memang kemanfaatan tersebut tidak berbeda karena perbedaan pihak yang memanfaatkan, bahkan walaupun pihak yang menyewakan mensyaratkan pihak yang menyewa harus memanfaatkan dan menggunakan sendiri barang yang disewa tersebut sekalipun. Namun jika jenis pemanfaatannya berbeda, maka harus dengan izin si pemilik barang tersebut (pihak yang menyewakan).

Adapun al-ibaahah (pembolehan) adalah, izin untuk mengkonsumsi atau menggunakan sesuatu, seperti seseorang mengizinkan makanan atau buah-buahan miliknya, juga seperti izin yang bersifat umum untuk memanfaatkan dan menggunakan fasilitas-fasilitas umum seperti lewat dijalan, duduk ditaman-taman, masuk sekolahan dan tempat-tempat pengobatan, juga seperti izin khusus menggunakan sesuatu milik seseorang tertentu seperti menaiki kendaraannya atau tinggal dirumahnya. ${ }^{39}$

4 Sebab dan Cara Memperoleh Kepemilikan

Sebab- sebab tamalluk (memiliki) yang ditetapkan syara' ada 4:

a. Ihrazul al Mubahat(menimbulkan kebolehan)

Ihrazulmubahat memiliki benda-benda yang boleh dimiliki, atau menempatkan sesuatu yang boleh dimiliki di suatu tempat untuk dimiliki. untuk harta yang

${ }^{38}$ Ibid,..., h.454.

${ }^{39} \mathrm{Ibid}$. 
mubah atau harta yang tidak termasuk ke dalam milik yang dihormati (milik seseorang yang tidak sah) dan tak ada pula penghalang yang dibenarkan syara' untuk dimilikinya. Contohnya: Ikan di sungai, ikan di laut, hewan buruan, burung-burung di alam bebas, air hujan dan lain-lain. Kemudian memiliki bendabenda yang mudah dengan jalan ihraz, memerlukan dua syarat:

1) Benda itu tidak dikuasai orang lain lebih dahulu.

2) Maksud tamalluk (untuk memiliki).

b. Al Uqud (aqad)

Perikatan ijab dengan kabul secara yang disyari'atkan agama nampak bekasnya pada yang diakadkan itu. Barang atau harta itu dimiliki karena melalui akad (bil uqud) contohnya: lewat jual beli, hutang piutang, sewa menyewa, hibah atau pemberian dan lain-lain, yang termasuk ke dalam uqud dari segi menjadi sebab milkiyah atau malakiyah:

1) Uqud jabariyah, yaitu akad-akad yang harus dilakukan berdasarkan kepada keputusan hakim, seperti menjual harta orang yang berhutang secara paksa. ${ }^{40}$

2) Istimlak untuk maslahat umum, seperti tanah-tanah yang disamping masjid, kalau diperlukan untuk masjid, harus dapat dimiliki oleh masjid dan pemilik harus menjualnya, ini dikatakan tamaluk bil jabri. (pemillikan dengan paksa.

c. Al Khalafiyah (pewarisan).

Khalafiyah ialah Bertempatnya seseorang atau sesuatu yang baru di tempat yang lama yang telah hilang pada berbagai macam rupa hak contohnya: mendapat bagian harta pusaka dari orang tua, mendapat barang dari wasiat ahli waris.

d. Attawalludu minal mamluk (timbulnya kepemilikan dari benda yang dimiliki).

${ }^{40}$ Muhammad Hasbi Ash Shiddieqy, Pengantar Fiqh Muamalah...,h.12. 
Tawallud min Mamluk yaitu segala yang terjadi dari benda yang telah dimiliki, menjadi hak bagi yang memiliki benda tersebut. Contohnya: Telur dari ayam yang dimiliki, anak sapi dari sapi yang dimiliki, bulu domba menjadi milik pemilik domba, dan lain-lain.

Sedangkan menurut hukum atau Undang-undang Sipil, sebab-sebab kemunculan kepemilikan sempurna ada enam, yaitu, menguasai sesuatu baik harta bergerak maupun harta tidak bergerak yang tidak bertuan, waris, dan tashfiyatut tirkah, wasiat, sesuatu yang menempel pada harta tidak bergerak atau harta bergerak , akad, al-hiyaazah dan at-taqaadum..$^{41}$

Sebab-sebab ini sesuai dengan sebab-sebab kepemilikan sempurna menurut syariat, kecuali sebab yang terakhir, yaitu al-hiyaazah dan at-Taqaadum (meletakkan kekuasaan atas harta milik orang lain sejak lama). Karena Islam tidak mengakui prinsip at-taqaadumal-muksib (at-taqaadum yang menjadikan pihak yang bersangkutan sebagai pemiliknya) sebagai sebab munculnya hak milik. Akan tetapi itu hanya sekedar sebagai faktor penyebab tidak diterimanya klaim hak milik yang telah lama berlalu untuk waktu tertentu. Hal ini sebagai bentuk penghematan terhadap masa peradilan supaya tidak terlalu berlarut-larut, menghadiri berbagai kendala pembuktian yang dimunculkan dan karena adanya keraguan terhadap asal hak milik. Adapun asal hak milik, maka secara agama harus tetap diakui sebagai milik pihak yang memilikinya secara sah dan hak itu tetap diberikan kepadanya secara penuh. Oleh karena itu, barang siapa meletakkan kekuasaannya atas suatu harta milik orang lain, maka menurut syara' ia tetap tidak bisa memilikinya sama sekali. ${ }^{42}$

Wahbah Az-Zuhayli, al-Fiqh al-Islam wa Adillatuhu, Terj: Abdul Hayyie al-Kattani, dkk...,h.462.

${ }^{42}$ Ibid. 
Pada dasarnya suku cadang ialah suatu komponen dalam kendaraan yang mana berpengaruh dalam kerja dari sepeda motor tersebut. Suku cadang adalah komponen dari mesin yang dicadangkan untuk perbaikan atau penggantian bagian kendaraan yang mengalami kerusakan. ${ }^{43}$ Yang penulis maksudkan dari suku cadang bekas adalah suatu suku cadang bekas pakai atau pernah dipakai dan setelah diperbaiki untuk dijual dengan harga lebih murah dari harga suku cadang baru.

Sedangkan suku cadang bekas pada skripsi ini ialah suku cadang bekas sepeda motor dimana karyawan bengkel di Desa Upah Kecamatan Bendahara Kabupaten Aceh Tamiang saat memperbaiki kendaraan tersebut mengabil suku cadang bekas tanpa meminta ijin pada pemilik suku cadang bekas tersebut, lalu diperbaiki suku cadang bekas tersebut dan dijual kembali kepada konsumen yang lain.

Ada banyak suku cadang bekas yang dijual di bengkel di desa Upah Kecamatan Bendahara Kabupaten Aceh Tamiang. Adapun suku cadang bekas sangat beragam yang dijual seperti rantai, baterai, karburator, dan lain-lain. Pemanfaatan suku cadang bekas bertujuan untuk mengurangi pengeluaran biaya dalam memperbaiki sepeda motor sehingga lebih murah. Contahnya seperti rantai bekas dengan harga Rp 30.000, yang lebih murah dari pada harga rantai baru yang mencapai \pm Rp 100.000. dengan harga yang murah tersebut konsumen bisa mengantiakn suku cadang bekas tersebut walaupun dengan uang sedikit.

\section{METODE PENELITIAN}

Jenis penelitian ini adalah penelitian lapangan (fild research) dengan mencari sumber data secara langsung dilapangan. ${ }^{44}$ Metode yang digunakan dalam penelitian ini adalah deskriptif kualitatif. Penelitian dengan format deskriptif bertujuan untuk mendeskriptifkan,

\footnotetext{
${ }^{43}$ https://id.wikipedia.org/wiki/ Onderdil (sukucadang) diakses pada tanggal 27 mei 2019 pada pukul 12:16 WIB.

${ }^{44}$ Soejarno soekarto, pengantar penelitan hukum, cet. Ke-3 (Jakarta: UI Press, 1998), h.6.
} 
meringkas berbagai kondisi, berbagai fenomena realitas yang ada di masyarakat yang menjadi objek penelitian. ${ }^{45}$ Sedangkan kualitatif adalah jenis penelitian yang kompleks dan luas yang mempunyai maksud untuk memahami suatu fenomena yang terjadi dilingkungan dan memerankan dirinya secara aktif dalam keseluruhan proses studi. Oleh karena itu, temuantemuan dalam studi kualitatif sangat dipengaruhi oleh nilai dan persepsi penelitian dimana data hasil penelitian dilakukan dalam bentuk kalimat uraian. ${ }^{46}$ Dalam penelitian ini, data digunakan untuk meriset mengenai Tinjauan Fiqh Muamalah Terhadap Jual Beli Suku Cadang Bekas Sepeda Motor Di Bengkel Desa Upah Kecamatan Bendahara Kabupaten Aceh Tamiang.

Penelitian yang peneliti lakukan berlokasi Bengkel di Desa Upah, Kecamatan Bendahara, Kabupaten Aceh Tamiang. Lokasi ini dipilih sebagai tempat penelitian dikarenakan penelitian melihat bahwa dalam praktik Jual Beli Suku Cadang Bekas Sepeda Motor Di Bengkel Desa Upah Kecamatan Bendahara Kabupaten Aceh Tamiang yang dilakukan oleh sebagaian karyawan telah terjadi ketidakserasian antara jual beli yang diatur dalam Islam dengan praktik yang terjadi dilapangan.

Penelitian ini menggunakan pendekatan normatif sosiologis. pendekatan penelitian normatif sosiologis berhubungan dengan implementasi ketentuan hukum normatif pada setiap peristiwa hukum yang terjadi dalam suatu masyarakat. Pendekatan normatif dilakukan dengan cara meneliti bahan pustaka atau data sekunder sebagai bahan dasar untuk diteliti dengan menggali hukum-hukum. Dalam hal ini peneliti menggali hukum-hukum dengan menggunakan hukum Islam terkait jual-beli yang berpedoman pada al-Quran dan hadis sedangkan pendekatan sosiologis dilakukan dengan cara melihat fakta-fakta yang terjadi di lapangan yang berhubungan dengan aspek-aspek hukum dalam interaksi sosial di dalam masyarakat. ${ }^{47}$

\footnotetext{
${ }^{45}$ Burhan Bungin, penelitian kualitatif, cet. Ke-2, (Jakarta: kencana prenada media Group, 2007), h. 68.

${ }^{46}$ Sudarwan Danim, Menjadi Peneliti Kualitatif, (Bandung: CV. Pustaka Setia, 2002), h.35.

${ }^{47}$ Margono, MetodologiPenelitian, (Jakarta: PT RinekaCipta, 1997), h. 108
} 
Dalam penelitian ini, penelitian melakukan observasi non partisipan. Peneliti datang ke tempat kegiatan orang yang akan diamati tetapi tidak ikut terlibat dalam kegiatan tersebut observasi yang dilakukan dengan cara pengamatan pada saat terjadinya transaksi jual beli yang dilakukan antara karyawan bengkel dengan konsumen yang membeli suku cadang bekas dengan menjual tanpa seijin pemilik suku cadang bekas tersebut.

Dalam penelitian ini, analisis data dimulai dengan mengumpulkan seluruh data yang didapatkan dari proses wawancara observasi dan sumber-sumber lainnya. Kemudian data yang terkumpul dipelajari dan dipahami Apakah sudah sesuai dengan yang diharapkan. setelah data dipelajari maka membuat Uraian singkat dan menghubungkannya dengan menggunakan teoriteori yang akan dipaparkan di babselanjutnya. Yang telah disusun dibandingkan antara satu dengan lain, kemudian dibuat kesimpulan yang merupakan tahap akhir dalam analisis data mengenai Tinjauan Fiqh Muamalah Terhadap Jual Beli Suku Cadang Bekas Sepeda Motor.

\section{HASIL PENELITIAN}

Desa Upah merupakan salah satu desa yang terdapat pada kecamatan Bendahara di Kabupaten Aceh Tamiang, letaknya yang strategis yaitu berada digerbang masuk kecamatan Bendahara yang sering dilalui oleh pengguna jalan dan dekat pula dengan perkampungan lainnya serta mudah diakses. Para pengusaha bengkel yang memperbaiki kendaraan di desa tersebut sudah menjalani profesinya sebagai pengusaha bengkel yang berkisar antara dua hingga sepuluh tahun lamanya.

Sistem dalam memperbaiki kendaraan konsumen yang ingin diperbaiki yaitu dengan mengantikan suku cadang yang telah berkurang fungsinya atau yang telah rusak dengan yang baru. Dalam memperbaiki kendaraan yang rusak konsumen dapat memilih suku cadang dengan dua cara yaitu pertama, membeli suku cadang yang baru dan kedua karyawan menawarkan dengan suku cadang bekas. 
Di mana suku cadang bekas tersebut diperoleh karyawan dalam memperbaiki kendaraan konsumen yang telah berkurang manfaatnya dengan diambil tanpa minta izin kepada konsumen dan jika konsumen tersebut meminta kembali suku cadang bekas tersebut maka suku cadang bekas tersebut dikembalikan kepada konsumen yang memperbaiki kendaraannya tersebut. Dari suku cadang bekas tersebut diperbaiki lagi sehingga bisa digunakan lagi dan dijual kepada masyarakat dengan harga yang elastis murah dari pada yang baru.

Perkiraan harga suku cadang bekas tersebut tergantung pada suku cadangnya jika masih bagus maka harganya lebih murah 60\% dari harga barunya, jika harga barunya Rp 100.000 maka harga suku cadang bekasnya Rp 60.000. Dan jika suku cadangnya kurang bagus maka harganya lebih murah lagi, diperkirakan $30 \%$ dari harga barunya jika harga barunya Rp 100.000 maka harga bekasnya Rp 30.000 .

Dengan sistem penjualan suku cadang bekas yang terjadi di Desa Upah Kecamatan Bendahara Kabupaten Aceh Tamiang, berikut ini hasil wawancara penulis dengan Nurmansyah selaku karyawan bengkel di desa Upah:

"Saya sudah berkerja di bengkel kurang lebih 5 tahun lamanya didesa Upah suku cadang yang telah digantikan dengan yang baru maka suku cadang bekas itu akan menjadi milik karyawan karena saya beranggapan bahwa konsumen tidak perlu lagi karena sudah digantikan dengan yang baru karena konsumen tidak miminta kembali suku cadang bekas tersebut."

Jika konsumen tersebut meminta suku cadang bekas tersebut maka saya kembalikan. Jika karyawan tidak meminta suku cadang bekas tersebut maka saya ambil dan saya perbaiki lagi suku cadang bekas tersebut dan saya jual kembali kepada konsumen yang membutuhkan dengan harga yang murah.

Disini jika konsumen memperbaiki kendaraan saya memberi opsi dalam suku cadang yang akan diganti itu dengan 2 pilihan yang pertama dengan yang baru dan yang kedua dengan yang bekas, dalam hal ini jika konsumen meminta yang bekas maka saya gantiakan dengan yang bekas" 48

Dari wawancara di atas dapat di simpulkan bahwa sistem dalam pengambilan suku cadang bekas tersebut dikarenakan konsumen yang memperbaiki kendaraan tersebut tidak meminta suku cadang bekasnya maka karyawan beranggapan bahwa itu tidak digunakan lagi

\footnotetext{
${ }^{48}$ Nurmansyah, karyawan bengkel di Desa Upah, wawancara pribadi di Desa Upah, 27/Juli/2020.
} 
oleh konsumen dan diambil oleh karyawan tanpa meminta izin dikarenakan konsumen tersebut tidak membutuhkannya lagi jika konsumen membutuhkannya maka suku cadang tersebut diserahkan kepada konsumen jika tidak maka akan jadi milik karyawan tersebut dan menjualnya kembali dengan harga yang murah.

Dalam wawancara lainnya penulis juga mewawancarai Irfan selaku karyawan bengkel di desa Upah:

"Saya bekerja di bengkel sepeda motor ini sekitaran 4 tahun, setiap saya memperbaiki kendaraan suku cadang yang telah diganti saya ambil dan saya kumpulkan untuk saya perbaiki lalu saya jual kembali, yang tidak bisa diperbaiki saya jual kepada tukang butut. Sepengetahuan saya dalam hal ini suku cadang bekas di bengkel-bengkel desa Upah selalu mengumpulkan suku cadang bekas diambil tanpa meminta izin pemilik suku cadang bekas tersebut semasa saya menjadi karyawan bengkel

Dalam menawarkan suku cadang bekas selama saya bekerja tidak ada keluhan terhadap suku cadang bekas yang saya jualkan dan kendala lainnya terhadap suku cadang tersebut." 49

Dari wawancara di atas dapat disimpulkan bahwa praktek jual beli suku cadang bekas sepeda motor memang sudah menjadi kebiasaan dalam memperbaiki kendaraan yang mana suku cadang yang telah diperbaiki dan diganti dengan yang baru maka suku cadang bekas tersebut diambil oleh karyawan dan diperbaiki dan dijual kembali dan suku cadang yang tidak bisa diperbaiki dijual kepada tukang butut, dalam hal ini konsumen pun tidak ada keluhan terhadap suku cadang tersebut.

Dalam wawancara lainnya penulis juga mewawancarai dedi selaku karyawan bengkel di desa Upah

"Saya bekerja di bengkel sepeda motor ini sekitaran 6 tahun, dalam memperbaki kendaraan saya menawarkan kepada konsumen dalam memperbaikinya dengan suku cadang bekas atau dengan suku cadang yang baru, dan setelah saya perbaikinya suku cadang bekas tersebut saya ambil dan saya perbaiki lagi lalu saya jualkan kembali. Dalam hal ini konsumen tidak banyak yang protes terhadap suku cadang bekas tersebut dikarenakan konsumen tidak membutuhkannya lagi. Tidak banyak konsumen yang meminta kembali suku cadang bekas tersebut dari persentanse hanya 5\% yang meminta kembali suku cadang bekas tersebut." 50

\footnotetext{
${ }^{49}$ Irfan, karyawan bengkel di Desa Upah, wawancara pribadi di Desa Upah, 27/Juli/2020.

${ }^{50}$ Dedi, karyawan bengkel di Desa Upah, wawancara pribadi di Desa Upah, 27/Juli/2020.
} 
Dari hasil wawancara tersebut dapat disimpulkan bahwa dalam mengambil suku cadang tersebut konsumen tidak keberatan dikarenakan konsumen tersebut tidak meminta kembali suku cadang bekas tersebut.

Dalam wawancara lainnya penulis juga mewawancarai Khairul selaku karyawan bengkel di desa Upah

"Saya bekerja di bengkel sepeda motor ini sekitaran 4 tahun, saat saya memperbaiki kendaraan sepeda motor saya menggantikan suku cadang yang rusak dengan yang baru, suku cadang yang rusak tersebut saya kumpulkan dan saya jual kepada tukang butut dan tidak saya kembalikan ke pemilik dengan sebab pemilik suku cadang bekas tersebut tidak meminta kembali suku cadang bekas tersebut, saya beranggapan suku cadang bekas tersebut tidak dibutuhkan lagi oleh pemilik nya jadi dari pada terbuang begitu saja lebih baik suku cadang bekas tersebut didaur ulang lagi dengan cara dijual kepada tukang butut sehingga tidak terjadinya mubazir. "51

Dari hasil wawancara tersebut dapat disimpulkan bahwa dalam mengambil suku cadang tersebut karyawan tidak meminta izin kepada pemilik suku cadang bekas tersebut dan mengambilnya begitu saja dengan alasana tidak terjadinya mubazir karena pemilik suku cadang bekas tersebut tidak meminta kembali suku cadang bekas tersebut berarti pemiik tersebut tidak membutuhkannya lagi.

Dalam wawancara lainnya penulis juga mewawancarai Ijal selaku karyawan bengkel di desa Upah

"Saya bekerja di bengkel sepeda motor ini sekitaran 7 tahun. Dalam memperbaiki kendaraan sepeda motor saya mengantikan suku cadang yang bekas dengan yang baru dimana suku cadang yang sudah diganti dan yang bekasnya tersebut saya ambil dan saya jual kepada tukang butut dalam hal suku cadang bekas tersebut konsumen yang memperbaiki kendaraan dan suku cadang bekas tersebut konsumen tidak meminta kembali suku cadang bekas tersebut dan konsumen meninngalkannya begitu saja. "52

Dari hasil wawancara tersebut dapat disimpulkan bahwa pelaku karyawan yang menggambil suku cadang bekas tersebut tidak meminta izin terhadap pemilik suku cadang bekas dikarenakan karyawan tersebut beranggapan bahwa suku cadang bekas tersebut tidak

\footnotetext{
${ }^{51}$ Khairul, karyawan bengkel di Desa Upah, wawancara pribadi di Desa Upah, 06/agustus/2020

${ }^{52}$ Ijal,karyawan bengkel di Desa Upah, wawancara pribadi di Desa Upah, 06/September/2020
} 
dibutuhkan lagi dan ditinggalkan begitu saja tanpa ada Ijab dan Kabul terhadap suku cadang bekas tersebut.

Dalam wawancara lainnya penulis juga mewawancarai seorang yang memperbaiki kendaraan di desa Upah bernama udin:

"Saya setiap memperbaiki kendaraan saya yang rusak kepada bengkel di desa Upah dalam memperbaiki mana yang perlu digantikan saya ganti dengan yang baru dan suku cadang yang bekas itu tidak saya ambil dan saya tinggal kan begitu saja karena saya tidak membutuhkannya tanpa saya serahkan ke karyawan yang memperbaiki nya dan saya ikhlas suku cadang tersebut diambl oleh karyawan tersebut." 53

Dari hasil wawancara di atas dapat disimpulkan bahwa dalam memperbaiki kendaraan yang rusak, konsumen menggantikan suku cadang yang baru dan meninggalkan suku cadang bekas dan ditinggalkan begitu saja tanpa ada serah terima dari suku cadang bekas tersebut dan konsumen pun ikhlas terhadap suku cadang bekas tersebut.

Dalam wawancara lainnya penulis juga mewawancarai seorang yang memperbaiki kendaraan di desa Upah bernama bapak maman.

"Setiap kendaraan saya yang rusak saya selalu membawa kendaraan saya di bengkel bertempat di desa Upah dan diperbaiki dengan baik dan dalam keadaan uang yang sedikit pun saya bisa memperbaiki kendaraan saya dikarena di bengkel ini menyediakan suku cadang bekas dan jika ingin yang bagus tersedia juga suku cadang baru,dalam hal ini saya tidak keberatan walaupun tidak tahan lama setidaknya kendaraan saya bisa digunakan untuk mencari uang lagi. Dan suku cadang yang sudah saya gantikan tadi saya tinggalkan begitu saja dan dalam hal ini saya mengikhlaskan suku cadang bekas tersebut digunakan karena saya tidak membutuhkannya lagi. "54

Dari hasil wawancara di atas dapat disimpulkan bahwa dalam memperbaiki kendaraan yan rusak tadi konsumen tidak keberatan dengan digantikan suku cadang bekas tersebut dan konsumen merasa dimudahkan dengan adanya suku cadang bekas walaupun dengan uang yang sedikit konsumen bisa memperbaiki kendaraannya. Dan suku cadang yang digantikan tadi ditinggalkan begitu saja dan dalam hal tersebut konsumen mengikhlaskan suku cadang

\footnotetext{
${ }^{53}$ Udin, konsumen yang memperbaiki kendaraan di Desa Upah, wawancara pribadi di Desa Upah, 04/September/2020.

${ }^{54}$ Bapak Maman, konsumen yang memperbaiki kendaraan di Desa Upah, wawancara pribadi di Desa Upah, 27/Juli/2020.
} 
bekas tersebut dimaanfaatkan karyawan tersebut dikarenakan konsumen tidak membutuhkannya lagi.

Dalam wawancara lainnya penulis juga mewawancarai seorang yang memperbaiki kendaraan di desa Upah bernama bapak Havis.

"Setiap kendaraan saya yang rusak saya bawa kebengkel di desa Upah tersebut dalam memperbaiki kendaraan tersebut karyawan menawarkan suku cadang yang baru dan bekas dalam hal tersebut ketika saya kekurangan uang saya selalu mengatikan dengan suku cadang bekas dan jika ada uang saya ganti dengan yang baru, dalam hal ini saya sangat senang memperbaiki kendaraan di bengkel ini karena dalam keadaan uang sedikit pun bisa diperbaiki, namanya juga kendaraan jika mau rusak mana tau keadaan orang taunya mau ada uang tidaknya,

Suku cadang yang tidak dipakai tadi saya tinggalkan saja karena saya pun tidak ada gunanya dan saya tinggal begitu saja kalau saya ambil pun buat capek saya bawanya karena tidak ada gunanya dan saya mengikhlaskan suku cadang bekas tersebut digunakan oleh karyawan tersebut. " 55

Dari hasil wawancara di atas dapat disimpulkan bahwa dalam memperbaiki kendaraan konsumen sangat senang dengan adanya suku cadang bekas tersebut dan suku cadang yang bekas tersebut konsumen meniggalkannya begitu saja dan tidak keberatan dengan suku cadang tersebut karena konsumen tersebut tidak membutuhkannya lagi dan konsumen tersebut mengikhlaskan suku cadang bekas tersebut digunakan karyawa tersebut.

Dalam wawancara lainnya penulis juga mewawancarai seorang yang memperbaiki kendaraan di desa Upah bernama bapak Andi.

"Setiap saya memperbaiki kendaraan saya yang rusak selalu saya bawa ke bengkel desa Upah, dan pelayanan di bengkel tersebut sangat baik bagus dan saya selalu memperbaiki kendaraan dengan suku cadang yang baru dan suku cadang yang bekas tersebut saya tinggalkan begitu saja karena saya tidak membutuhkannya lagi dan saya tidak keberatan suku cadang bekas tersebut diambil oleh karyawan tersebut."56

Dari hasil wawancara di atas dapat disimpulkan bahwa dalam memperbaiki kendaraan konsumen sangat senang dengan pelayanan di bengkel desa Upah dan konsumen selalu menggantikan suku cadang kendaraannya dengan suku cadang yang baru dan suku cadang

\footnotetext{
${ }^{55}$ Bapak Havis, konsumen yang memperbaiki kendaraan di Desa Upah, wawancara pribadi di Desa Upah, 04/agustus/2020.

${ }^{56}$ Bapak Andi, konsumen yang memperbaiki kendaraan di Desa Upah, wawancara pribadi di Desa Upah, 06/agustus/2020.
} 
bekas tersebut ditinggalkan begitu saja dikarenakan konsumen tidak membutuhkan suku cadang bekas tersebut dan konsumen tidak keberatan jika suku cadang bekas tersebut diambil oleh karyawan tersebut. .

Dalam wawancara lainnya penulis juga mewawancarai seorang yang memperbaiki kendaraan di desa Upah bernama bapak ucok.

"Saya dari dulu setiap kendaraan saya yang rusak selalu saya bawa di bengkel desa Upah ini dengan karyawannya yang baik dan pelayanan yang bagus, dan sangat memuaskan.

Kendaraan saya yang rusak saya perbaiki dengan suku cadang yang baru dan suku cadang bekas yang sudah saya ganti saya lihat kembali jika masih bisa saya gunakan saya minta kembali jika tidak, saya tinggalkan begitu saja. Suku cadang bekas tersebut saya tinggalkan dengan ikhlas. ",57

Dari hasil wawancara di atas dapat disimpulkan bahwa setiap kendaraan yang rusak selalu diperbaiki di desa Upah Kecamatan Bendahara kabupaten Aceh Tamiang dengan karyawannya yang baik dan pelayanan yang bagus dan sangat memuaskan. Kendaraan yang rusak diganti suku cadang dengan yang baru dan suku cadang bekas tersebut jika masih bisa digunakan diambil oleh konsumen dan jika tidak bisa digunakan maka ditinggalkan begitu saja, dan suku cadang yang ditinggalkan oleh konsumen dengan rasa ikhlas.

Jual beli adalah saling menukar harta dengan harta dalam bentuk pemindahan milik dan pemilikan dengan mengunakan akad. Jual beli suku cadang bekas sepeda motor pada dasarnya tidak dibahas secara rinci didalam Islam serta tidak ada dalil al-Quran dan hadis yang menyebutkan hukum dari jual beli suku cadang bekas sepeda motor. Terkait hukum boleh atau tidaknya, dalam transaksi muamalah terkait jual beli ada ketentuan terkait rukun dan syarat yang harus dipenuhi dan berpengaruh sah dan tidak sahnya suatu transaksi yang dilakukan.

\footnotetext{
${ }^{57}$ Bapak Ucok, konsumen yang memperbaiki kendaraan di Desa Upah, wawancara pribadi di Desa Upah, 06/September/2020.
} 
Didalam jual beli suku cadang bekas dalam rukun jual beli sudah terpenuhi, seperti adanya orang yang berakad, adanya Sighat, adanya barang, serta adanya harga terhadap barang. Setelah terpenuhinya rukun jual beli, maka harus terpenuhinya syarat dalam jual beli, dalam jual beli ini syarat jual beli seperti yang pertama orang yang berakad haruslah berakal. Syarat kedua ijab Kabul dalam ijab Kabul haruslah ada kerelaan dari dua belah pihak. Syarat ketiga uang atau nilai tukar barang tersebut haruslah suci, ada manfaatnya. Dan yang keempat barang yang diperjualbelikan seperti barang itu ada, dapat dimanfaatkan, milik pihak penjual, dan pada jual beli suku cadang bekas barang tersebut bukan milik dari penjual. Maka dalam jual beli suku cadang bekas syarat terhadap barang tersebut tidak memenuhi syarat yaitu barang tersebut masih milik konsumen yang asli.

Jual Beli Suku Cadang Bekas Sepada Motor Di Desa Upah Kecamatan Bendahara Kabupaten Aceh Tamiang, terdapat 5 karyawan bengkel dengan bengkel yang berbeda-beda yang menjual suku cadang bekas tanpa meminta izin kepada pihak pemilik suku cadang bekas tersebut. Oleh karena itu, pada dasarnya hak kepemilikan atas suku cadang tersebut masih hak milik konsumen yang asli. Penjualan suku cadang bekas tersebut tidak meminta ijin kepada pemilik suku cadang bekas tersebut sehingga jual beli suku cadang bekas tersebut tidak memenuhi syarat yang sesuai dengan syariat yang dibenarkan oleh syara'.

Sedang jika dilihat dari dalam kepemilikan dalam Islam karyawan yang menjual suku cadang bekas tersebut tidak termasuk kedalam kepemilikan sempurna maupun kepemilikan tidak sempurna dimana ditinjau dari sebab-sebab kepemilikan dalam Islam. Sebab-sebab dari tamalluk (memiliki) yang ditetapkan syara' ada 4 yaitu Ihrazul al Mubahat(menimbulkan kebolehan), Al Uqud( akad), Al Khalafiyah (pewarisan), serta Attawalludu minal mamluk (timbulnya kepemilikan dari benda yang dimiliki).

Dari sebab-sebab kepemilikan tersebut maka jual beli suku cadang bekas di Desa Upah Kecamatan Bendahara Kabupaten Aceh Tamiang, maka hak milik dari objek dari suku cadang 
bekas tersebut yang diperoleh oleh karyawan bengkel di Desa Upah tersebut bukan milik karyawan tersebut karena tidak masuknya dalam sebab-sebab memperoleh kepemilikan.

Maka dengan itu suku cadang bekas sepeda motor tersebut bukan lah milik karyawan melainkan milik konsumen dan jual beli tersebut tidaklah boleh dilanjutkan lagi karena tidak memenuhi syarat jual beli dalam Islam.

Dari hasil penelitian yang sudah dilakukan oleh peneliti terhadap Jual Beli Suku Cadang Bekas Di Desa Upah Kecamatan Bendahara Kabupaten Aceh Tamiang ini sudah lama adanyan dan menjadi kebiasaan masyarakat di Desa Upah Kecamatan Bendahara Kabupaten Aceh Tamiang. Suku cadang bekas ini diambil dari milik konsumen yang sudah diganti dengan yang baru dan yang bekas tersebut diambil oleh karyawan tersebut dan dijual kembali jika bisa diperbaiki. Saat konsumen meminta kembali suku cadang bekas tersebut maka karyawan tersebut harus mengembalikan suku cadang bekas tersebut kepada pemiliknya (konsumen).

Beberapa konsumen lainya lebih suka dan tidak keberatan terhadap membeli suku cadang bekas tersebut alasannya dikarenakan dengan harga yang murah kendaraan yang rusak tersebut bisa diperbaiki walaupun dengan uang sedikit.

Selain itu juga terdapat standar suku cadang bekas dikonversi dari harga, dimana para karyawan menetapkan harga dari setiap suku cadang bekas yang didasarkan pada harga yang lebih murah dari harga baru tersebut. Yang kemudian ditaksir oleh para karyawan untuk dapat menetapkan beberapa harga dalam setiap suku cadang bekas tersebut.

Dalam menentukan harga, penjual menentukan harganya sendiri di setiap suku cadang bekas yang dimana harga tersebut jika harga barunya Rp 100.000 maka harga suku cadang bekas tersebut berkisaran antara Rp 50.000. Jual beli suku cadang bekas dari segi tinjauan 'Urf itu tidak sah, hal ini dikarenakan dalam transaksi tersebut tidak memenuhi syarat jual beli, dimana kepemilikana tersebut masih milik pihak asli secara hak kepemilikan dalam Islam. Walaupun banyak responden yang meridakan suku cadang bekas tersebut tetapi responden 
tidak menyerahkan kepada karyawan dan sebaliknya pihak karyawan pun tidak meminta kepada pemilik suku cadang bekaas tersebut. Seperti dalam konsep keridaan jika seseorang saling rida tetapi melanggar hukum syara' maka hal tersebut tidak bisa dilanjutkan (batal) jual beli tersebut.

Dalam analisis penulis jual beli suku cadang bekas yang terjadi di bengkel Desa Upah Kecamatan Bendahara Kabupaten Aceh Tamiang itu termasuk kedalam 'Urf fasid yaitu 'Urf yang bertentangan dengan syariat. Dikarenakan sebagian dari transaksi yang dilakukan di bengkel Desa Upah Kecamatan Bendahara Kabupaten Aceh Tamiang dalam menjual suku cadang bekas, hal ini para pemilik asli dari suku cadang bekas tersebut tidak menyerahkan suku cadang bekas tersebut kepada karyawan dan sebaliknya karyawan tersebut tidak meminta langsung kepada pemilik suku cadang bekas tersebut ssehingga bertentangan dengan hukum syara'. Urf' tersebut bisa dijadikan dasar hukum harus memenuhi syarat yaitu tidak bertentangan dengan hukum syara' serta urf' tersebut haruslah urf'sahih.

Dalam segi keridaan dalam barang tersebut jual beli tersebut dikatakan sah, melainkan harus memenuhi rukun dan syarat jual beli sehingga jual beli tersebut sah secara hukum Islam. Tidak hanya dengan rida saja jual beli tersebut bisa dikatakan sah karena dalam hal tersebut harus terpenuhnya syarat jual beli.

Contohnya seperti hal nya dalam transaksi jual beli jika seseorang rida dalam transaksi jual beli khamar maka keridaan tersebut tidak lah sah dan itu tidak boleh dilakukan dan melanggar hukum syariat karena khamar tersebut ialah benda haram secara syariat. Sehingga jual beli khamar tersebut tidaklah sah dan batal karena khamar tersebut benda haram yang dilarang oleh syariat. Maka oleh itu dalam jual beli suku cadang bekas, keridaan tidak hanya dengan samasama rida melainkan rida tidak bertentangan dengan hukum syariat

\section{KESIMPULAN}

Berdasarkan penelitian yang di lakukan tentang jual beli suku cadang bekas sepeda motor di Desa Upah Kecamatan Bendahara Kabupaten Aceh Tamiang maka sebagai akhir dari tulisan ini penulis menarik beberapa kesimpulan sebagai berikut: 
1. Dalam segi praktiknya sistem jual beli suku cadang bekas konsumen diberikan opsi saat memperbaiki kendaraan dengan dua opsi yaitu dengan suku cadang yang baru dan suku cadang yang bekas. Dimana suku cadang bekas tersebut diperoleh dari milik konsumen yang mana suku cadang yang rusak telah diganti dengan yang baru dan yang suku cadang rusak tersebut diambil oleh karyawan tanpa meminta kepada pihak konsumen dan diperbaiki oleh karyawan tersebut dan dijual kembali dengan harga yang elastis murah dan terjangkau.

2. Praktik jual beli suku cadang bekas sepeda motor di bengkel Desa Upah Kecamatan bendahara Kabupaten Aceh Tamiang ditinjauan sacara Fiqh muamalah, jual beli suku cadang bekas sepeda motor ini tidak diperbolehkan, dikarenakan suku cadang bekas tersebut bukanlah milik karyawan sepenuhnya melainkan milik konsumen. Kepemilikan tersebut belum berpindah kepada karyawan, karena tidak terdapat salah satu dari sebab-sebab kepemilikan.

Setelah penulis menarik kesimpulan berdasarkan hasil penelitian, maka berikut ini penulis memberikan saran yang dapat berguna yaitu:

1. Bagi karyawan yang menjual suku cadang bekas tersebut dalam memperoleh suku cadang bekas harus meminta langsung kepada kepemilik suku cadang bekas tersebut. Agar dalam mendapatkan suku cadang bekas sesuai dengan syariat dan jual beli terjadi dengan sesuai secara syariat sehingga rejeki yang didapatkan menjadi berkah.

2. Bagi pembeli ketika membeli suku cadang bekas tersebut hati-hati dalam membeli suku cadang bekas tersebut karena yang namanya barang bekas dapat mempengaruhi kualitas barang. 


\section{DAFTAR PUSTAKA}

Abdul Aziz Muhammad Azzam, Fiqh Muamalat (Sistem Transaksi dalam Islam), Jakarta: Bumi Aksara, 2010.

Al Albani Nashruddin Muhammad, Shahih sunan ibnu Majah, Ter: Ahmad Taufik Abdurrahman, Jilid 2, Jakarta: Pustaka Azzam ,2007.

al-'Asqalani ibni hazar, Bulughul Maram, surakarta:Ziyad Books, 2017.

Az-Zuhayli Wahbah, al-Fiqh al-Islam WaAdillatuhu, Terj: Abdul Hayyie al-Kattani, dkk, Peny: Nuim Hidayat, jilid 6,cet: 1, Jakarta: Gema Insani, 2011.

Bakry Nazar, Fiqh dan ushul fiqh, Jakarta: RajaGrafindo Persada, 2003.

Bungin Burhan, penelitian kualitatif, cet. Ke-2, jakarta: kencana prenada media Group, 2007.

Bungin Burhan, Penelitian Kualitatif: Komunikasi, Ekonomi, kebijakan publik dan ilmu sosial lainnya, Jakarta: Kencana, 2009.

Dahlan Aziz Abdul, Dkk, Ensiklopedi Hukum Islam, Jakarta: PT Ichtiar Baru Van Hoeve, 1997.

Dahlan Rahman Abd, Ushul Fiqih, Jakarta: AMZAH, 2010.

Danim Sudarwan, Menjadi Peneliti Kualitatif, Bandung: CV. Pustaka Setia, 2002.

Departemen Agama RI, Al-Qur'an Tajwid dan Terjemah, Bandung: CV Penerbit Diponegoro, 2016.

Djuwani Dimyuddin, Pengantar Fiqh Muamalah, Yogyakarta: Pustaka Pelajar, 2008.

Efendi Satria, Ushul Fiqih, Jakarta, Prenada Media, 2005.

Fathoni Abdurrahman, Metodelogi Penelitian \& Teknik Penyusunan Skripsi, Jakarta: Pt Rineka Cipta, 2006.

Ghazaly Rahman Abdul, dkk, Fiqh Muamalat, Jakarta: Kencana Prenada Media Group, 2010.

Haroen Nasrun, Fiqh Muamalah, Jakarta:Gaya Media Pratama,2000.

Ibnu Qasim al-Ghazi,Fathul al-Qarib, Terj: Imron Abu Amar, Kudus: Menara Kudus,1982.

Katsir Ibnu, Tafsir Ibnu Katsir, jilid 1, terj: Salim Bahreisy dan Said Bahreisy, Jakarta: PT. Bina Ilmu, 2005.

Katsir Ibnu, Tafsir Ibnu Katsir, jilid 3 , terj: Arif Rahman Hakim dkk Surakarta: Insan Kamil, 2015. 
Khalaf Wahab Abdul, Ilmu Ushul Fiqh dalam Kaidah Hukum Islam, Jakarta, Sinar Grafika, 2003.

Mardalis, Metode Penelitian Suatu Pendekatan Proposal, Jakarta: BumiAksara, 2006.

Margono, MetodologiPenelitian, Jakarta: PT RinekaCipta, 1997.

Muhammad Hasbi Ash Shiddieqy,Pengantar Fiqh Muamalah, Semarang: Pustaka Rizki Putra, 1999.

Ruf ah Abdulah, Fikih Muamalah, Bogor: Ghalia Indonesia, 2011.

Sayid Sabiq, ,Fikih Sunnah, Semarang: Karya Toha Putra, 1999.

Soekarto Soejarno, pengantar penelitan hukum, cet. Ke-3 Jakarta: UI Press, 1998.

Sohari Sahrani dan Ru'fah Abdullah, Fikih Muamalah, Bogor: Ghalia Indonesia, 2011.

Suhendi Hendi, Fiqh Muamalah, Jakarta: PT Raja Grafindo, 2002.

Suhendi Hendi,Fiqh Muamalah, Jakarta: Rajawali, 2005.

Syarifuddin Amir, Garis-Garis Besar Fiqh, Jakarta: Kencana, 2003.

Syarifuddin Amir, Ushul Fiqih, Jakarta: Logos Wacana Ilmu, 1999.

Fransisca Richa, Jual beli oli bekas dalam perspektif hukum Islam (studi pada bengkel Federal di Kec krui, kab pesisir barat), (Skripsi, perpustakaan Universitas Islam Negeri Raden Intan Lampung, 2017).

Lestari Ayu Puji, Tinjauan Hukum Islam Tentang Akad Jual Beli Kain Sisa Jahitan(studi di Delia Busana Bandar Lampung), (Skripsi, perpustakaan Universitas Islam Negeri Raden Intan Lampung,2018)

Rahayu Cipta Aning, Pemanfaatan kain sisa jahitan oleh penjahit di Kota Langsa perspektif Fiqh Muamalah,(Skripsi, Perpustakaan Institut Agama Islam Negeri Langsa, 2018)

Setiawan Arief Dwi, Tinjauan hukum Islam terhadap praktek jual beli ban bekas di (Desa Kabunan Kecamatan Dukuhwaru Kabupaten Tegal), (Skripsi, perpustakaan Universitas Islam Negeri Walisongo Semarang, 2018).

Bapak Andi, konsumen yang memperbaiki kendaraan di Desa Upah, wawancara pribadi di Desa Upah, 06/November/2020.

Bapak Havis, konsumen yang memperbaiki kendaraan di Desa Upah, wawancara pribadi di Desa Upah, 04/agustus/2020.

Bapak Maman, konsumen yang memperbaiki kendaraan di Desa Upah, wawancara pribadi di Desa Upah, 27/Juli/2020.

Bapak Ucok, konsumen yang memperbaiki kendaraan di Desa Upah, wawancara pribadi di Desa Upah, 06/November/2020 
Dedi, karyawan bengkel di Desa Upah, wawancara pribadi, di Desa Upah, 27/Juli/2020.

Ijal, karyawan bengkel di Desa Upah, wawancara pribadi di Desa Upah, 06/November/2020

Irfan, karyawan bengkel di Desa Upah, wawancara pribadi di Desa Upah, 27/Juli/2020.

Khairul, karyawan bengkel di Desa Upah, wawancara pribadi di Desa Upah, 06/November/2020

Nurmansyah, karyawan bengkel di Desa Upah, wawancara pribadi di Desa Upah, 27/Juli/2020.

Udin, konsumen yang memperbaiki kendaraan di Desa Upah, wawancara pribadi di Desa Upah, 04/agustus/2020. 